\title{
Study on the High Rate Removal of Nitrogen in a Lagoon with Intermittent Aeration-III
}

\author{
On the Seasonal Variation of Mud and its Control
}

\author{
Kaoru MitsuHaSHI*
}

(Received April 6, 1979)

\begin{abstract}
In a intermittently aerated lagoon, in which a high rate of removal of nitrogen had been observed, a seasonal variation of mud on the bottom was investigated using a new mud sounder which consisted of ultraviolet lamps and a blueprint marker. The volume of mud ranged between 35 and $132 \mathrm{~m}^{3}$. The mud increased in winter and decreased in spring. The total amount of nitrogen found in the mud and mixed liquor was large in winter and spring and small in summer and autumn.

To control the increase of mud in winter, a treatment test was done for shallow lagoon water conditions. The results were that the volume of mud was maintained almost constant, the total amount of nitrogen found did not increase, and the rate of nitrogen removal remained high.
\end{abstract}

In previous papers ${ }^{1,21}$, it was described that a high rate removal of nitrogen was obtained in a lagoon with intermittent aeration and a mechanism to remove nitrogen compounds from waste water was partially clarified.

On the other hand, according to a classification of lagoons, there are a few types of lagoon ${ }^{3}$, one of which is an aerated lagoon, where some amount of sludge is accumulated on a bottom of the lagoon. As an example of such investigation on a pulp and paper mill waste, it was reported that approximately $0.1-0.2 \mathrm{lbs}$. of sludge was accumulating for $1 \mathrm{lb}$. of removed BOD ${ }^{4}$. However, few studies have been done on an amount of bottom mud.

In the present work. a bottom mud (accumulated sludge on the bottom) was investigated by using a newly deviced mud sounder, and in winter, time of lowest biological activity, the mud and a grand total of nitrogen reserved in the lagoon - were investigated to know whether it was possible to stop an increase of mud (or grand total of nitrogen) in the lagoon or not. If it was possible, the lagoon could be maintained without artificial removal of excess sludge for many years.

As mentioned in the previous paper ${ }^{21}$ an excess supply of oxygen causes a plenty of nitrate in effiuent water, extremely in winter. Therefore, the experiment has been done to avoid it at high concentration of Mixed Liquor Suspended Solid (MLSS) by diminishing a depth of treatment water in the lagoon, where an oxygen transfer from air to water will be small enough.

\section{Methods}

\section{Mud Sounding}

A depth of mud was measured by the mud sounder, of which construction was shown in Fig. 1. It consisted of an iron frame with 4 legs, one of them was replaceable with a blueprint stocking and a geminated ultraviolet lamp assembly, which was hung by fine strings, and of which weight in water was adjusted so light that it did not sink into mud. The lamp assembly in water was operated by a switch box of usual lamp lighting kit, which was made of choke coils, glow lamps and a switch, through 8 fine flexible electric cords. An operator with the switch box worked on a raft on the water surface. The blueprint stocking was prepared at dark room as follows. First a strip of paper was rolled and made in a form of paper pipe using glass tube. It was painted by blueprint solution and dried. After water-proof synthetic glue was applied, it was dried again and put on the replaceable leg by scotch tape, then the leg was covered by black envelope. Many spares of replaceable legs were prepared and kept in a portable dark case. A sounding operation was done as follows. One of replaceable leg was fixed in the place of the mud sounder by a screw bolt on the raft which was moored at a station and the black envelope was taken off just before the mud sounder was hung in water. After the legs reached to concrete bettom, a hanging twine was released so slowly that the lamp assembly was put on the surface of mud.

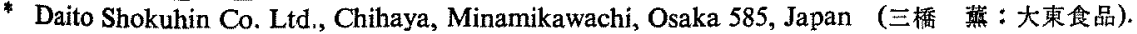


Lighting the lamps for 2 to $5 \mathrm{~min}$, the mud sounder was lifted and a distance between a lower end and a blue mark on the leg was measured. A

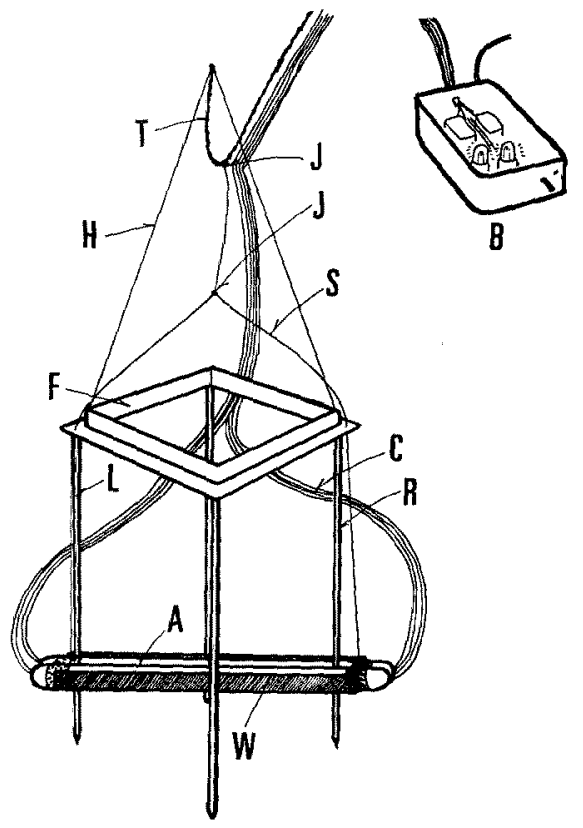

Fig. 1. Mud sounder.

A: Lamp Assembly, B: Switch Box, C: Electric Cords, F: Frame, H: Hanging Wire, J: Joint, L: Leg, R: Replaceable Leg, S: String, T: Hanging Twine, W: Weight.
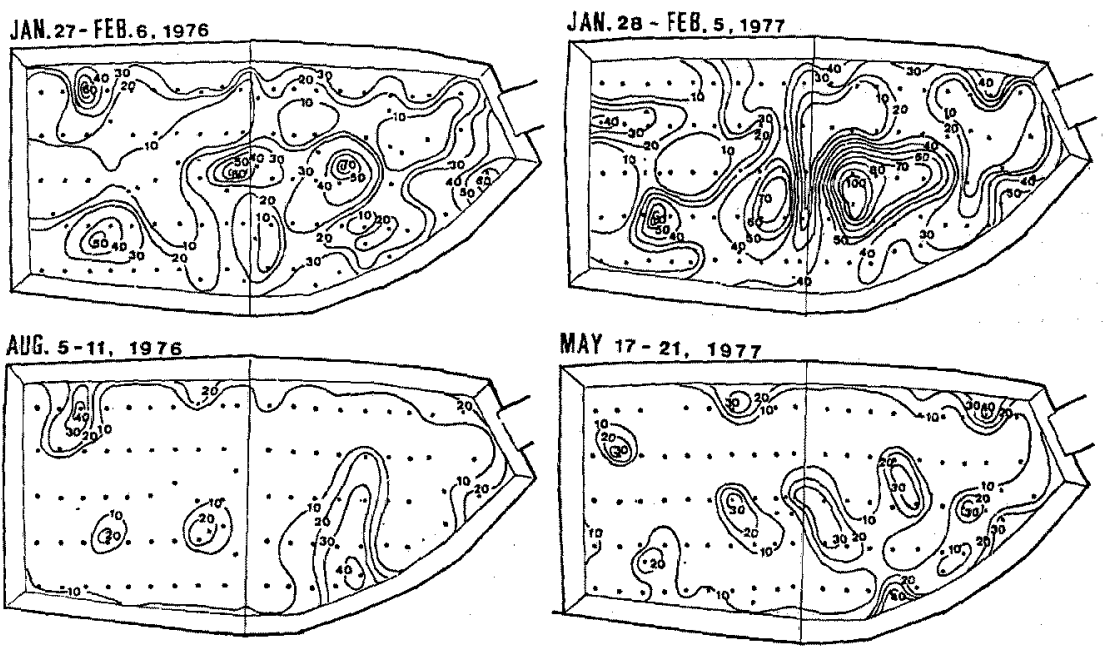

Fig. 2. Disposition charts of mud: Each number on contour line shows a depth of mud in $\mathrm{cm}$, Sounding stations are shown by dots.

disposition chart of mud was figured out by the observations at approximately one hundred stations set up at every $3 \mathrm{~m}$ in row and every $1.5 \mathrm{~m}$ in range. A volume of mud was calculated from the chart.

\section{Sampling}

A mud sample was collected by a piston collector with a long rod and a pulling twine. A mixed liquor sample was collected from $0.1 \mathrm{~m}$ deep of the water during the period of mixing by aerators. Influent and effluent samples were collected as the same as in the previous paper".

\section{Analysis}

The determination of nitrogen compounds in influent and effluent water and also inorganic nitrogen compounds in mud and mixed liquor were done by the same as in the previous paper". For organic nitrogen in mud and mixed liquor usually each sample of a small amount (1-22 mg) was taken into a bent test tube, which was used as a Kjeldahl flask ${ }^{5}$, directly or after centrifuged at $4000 \mathrm{rpm}$, and then weighed and decomposed by $\mathrm{HgO}, \mathrm{K}_{2} \mathrm{SO}_{4}$ and $\mathrm{H}_{2} \mathrm{SO}_{4}$. The determination of ammonium $\mathrm{N}$ was done by phenate method ${ }^{6)}$.

\section{Results}

\section{Seasonal Variation of $M$ ud}

Some examples of the disposition chart of mud were shown in Fig. 2. A total volume of mud on 


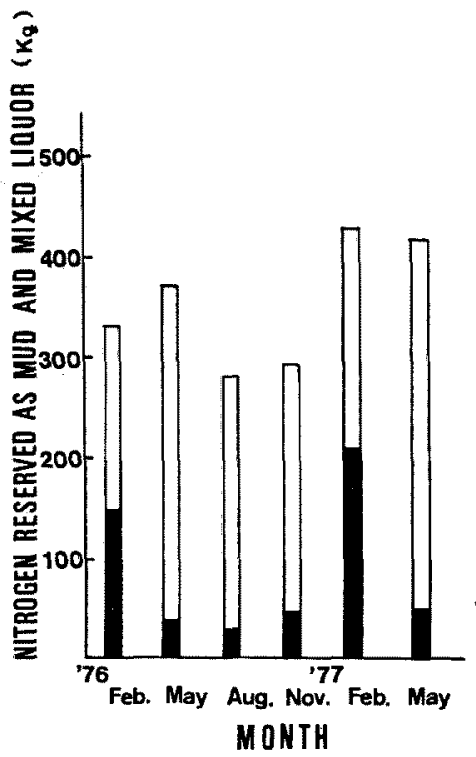

Fig. 3. Amount of nitrogen reserved in mud and mixed liquor: $\square \mathrm{N}$ in mud; $\square \mathrm{N}$ in mixed liquor.

Feb. 1, May 10, Aug. 8, Nov. 7 in 1976, Feb. 1 and May 19 in 1977 were calculated as $96,38,35,44$, 132 and $41 \mathrm{~m}^{8}$, respectively. The volume of mud in winter of 1977 was the biggest of those of seasons.

The amounts of nitrogen reserved in mud and mixed liquor in the lagoon were shown in Fig. 3. The nitrogen reserved in mud increased in winter and decreased in spring. The total nitrogen re- served in mud and mixed liquor was great in winter and spring and small in summer and autumn.

\section{Mud Control Test}

To control the increase of mud in winter a treatment test was done under the high concentration of MLSS and strong mixing condition of water with low DO by diminishing depth of lagoon water from 3.2 to $2.65 \mathrm{~m}$.

As shown in Tables 1 and 2, the concentration of MLSS increased from 3000 to $3800 \mathrm{ppm}$ with the increasing aeration time. A grand total of nitrogen reserved in mud and mixed liquor in the lagoon ranged from 440 to $460 \mathrm{Kg}$ for the period of test and did not show a tendency of increase though a total volume of mud increased approximately fifteen $\%$. Meantime, as shown in Tables 1 and 3, the removal rate of $\mathrm{N}$, concentrations of effluent total $\mathrm{N}$, effluent BOD and COD for the test period were $82-93 \%, 1.0-2.4 \mathrm{mg} / l, 2.4-6.0$ and $8.0-20 \mathrm{ppm}$, respectively.

\section{Discussion}

The mud control test in winter indicated that even under the low temperature condition, and it was possible to maintain almost the same amount of mud during the test period of winter and greatly to decrease it in comparison with the preceding winter.

The reason why the mud decreased greatly seems that the sludge was mixed intensively by aerators for longer time in smaller volume of lagoon water, while in winter 1976-'77 the sludge had settled on

Table 1. Mud control test in winter 1977-'78

\begin{tabular}{|c|c|c|c|c|c|c|c|}
\hline Period & $\begin{array}{l}\text { from } \\
\text { to }\end{array}$ & $\begin{array}{r}\text { Dec. } 21 \\
\text { Jan. } 11\end{array}$ & $\begin{array}{l}\text { Jan. } 12 \\
\text { Jan. } 31\end{array}$ & $\begin{array}{l}\text { Feb. } 1 \\
\text { Feb. } 20\end{array}$ & $\begin{array}{l}\text { Feb. } 21 \\
\text { Mar. } 10\end{array}$ & $\begin{array}{l}\text { Mar. } 11 \\
\text { Mar. } 31\end{array}$ & $\begin{array}{l}\text { Reference } \\
\text { Feb. } 1977\end{array}$ \\
\hline Depth of water $(\mathrm{m})$ & $\left\{\begin{array}{l}\max \\
\min \end{array}\right.$ & $\begin{array}{l}3.40 \\
3.02\end{array}$ & $\begin{array}{l}3.32 \\
2.46\end{array}$ & $\begin{array}{l}3.25 \\
2.50\end{array}$ & $\begin{array}{l}3.20 \\
2.50\end{array}$ & $\begin{array}{l}2.93 \\
2.50\end{array}$ & $\begin{array}{l}3.55 \\
3.05\end{array}$ \\
\hline Volume of water $\left(\mathrm{m}^{3}\right)$ & $\left\{\begin{array}{l}\max \\
\min \end{array}\right.$ & $\begin{array}{l}1729 \\
1516\end{array}$ & $\begin{array}{l}1740 \\
1215\end{array}$ & $\begin{array}{l}1721 \\
1235\end{array}$ & $\begin{array}{l}1617 \\
1235\end{array}$ & $\begin{array}{l}1521 \\
1235\end{array}$ & $\begin{array}{l}1811 \\
1535\end{array}$ \\
\hline MLSS (ppm) (mean) & & 3030 & 3820 & - & - & 4250 & 1790 \\
\hline $\begin{array}{l}\text { Aeration time for } 1 \mathrm{~h} \\
\text { off-aeration (min) }\end{array}$ & $\left\{\begin{array}{l}\max \\
\min \end{array}\right.$ & $\begin{array}{l}30 \\
20\end{array}$ & $\begin{array}{l}60 \\
15\end{array}$ & $\begin{array}{r}120 \\
30\end{array}$ & $\begin{array}{c}\text { Contin*1 } \\
30^{*}\end{array}$ & $\begin{array}{r}180 \\
90\end{array}$ & $\begin{array}{l}10 \\
10\end{array}$ \\
\hline \multicolumn{2}{|c|}{ Percent of adequate aeration $* 2$} & 69 & 53 & 29 & 52 & 94 & - \\
\hline \multicolumn{2}{|c|}{ Effluent BOD (ppm) } & 2.4 & 2.8 & 3.3 & 6.0 & 2.8 & 2.4 \\
\hline \multicolumn{2}{|l|}{. $\operatorname{COD}(" \pi)$} & 12.6 & 8.1 & 14.5 & 19.9 & - & 6.2 \\
\hline \multicolumn{2}{|c|}{$\begin{array}{l}\text { Settlement (hours spent to } \\
\text { reach } 40 \mathrm{~cm} \text { deep } * 3\end{array}$} & 4 & 6 & 8 & 一 & 4 & 1 \\
\hline \multicolumn{8}{|c|}{$\begin{array}{l}\text { A continuous aeration except time for settlement and effuence of water. } \\
\text { A percent of adequate aeration }=\text { Number of observations where the } \mathrm{NO}_{8} / \mathrm{NH}_{8} \text { ration was between } 1 \text { and } 10 / \mathrm{Number} \text { of } \\
\text { observations } \times 100 \text {. }\end{array}$} \\
\hline
\end{tabular}


Table 2. Nitrogen reserved in mud and mixed liquor

\begin{tabular}{crrr}
\hline Date & Dec. 22 '77 & Feb. 4'78 & Mar. 30'78 \\
\hline Bottom mud & & & 57.3 \\
Volume of mud $\left(\mathrm{m}^{3}\right)$ & 49.9 & 52.0 & 72.9 \\
Amount of $\mathrm{N}(\mathrm{kg})$ & 59.3 & 63.2 & 1,230 \\
\hline Mixed liquor & & & 319,000 \\
Volume of $\mathrm{ML}\left(\mathrm{m}^{3}\right)$ & 1,540 & 1,210 & 390 \\
Conc. of $\mathrm{N}(\mu \mathrm{g}-\mathrm{N} / \mathrm{l})$ & 268,000 & 311,000 & 463 \\
Amount of $\mathrm{N}(\mathrm{kg})$ & 403 & 439 & 46 \\
\hline
\end{tabular}

Table 3. Influent and effluent nitrogen

\begin{tabular}{|c|c|c|c|c|c|c|c|c|}
\hline \multicolumn{2}{|c|}{ Period } & \multicolumn{2}{|c|}{$\begin{array}{l}\text { from } \\
\text { to }\end{array}$} & $\begin{array}{l}\text { Dec. } 21 \\
\text { Jan. } 11\end{array}$ & $\begin{array}{l}\text { Jan. } 12 \\
\text { Jan. } 31\end{array}$ & $\begin{array}{l}\text { Feb. } 1 \\
\text { Feb. } 20\end{array}$ & $\begin{array}{l}\text { Feb. } 21 \\
\text { Mar. } 10\end{array}$ & $\begin{array}{l}\text { Mar. } 11 \\
\text { Mar. } 31\end{array}$ \\
\hline \multicolumn{9}{|l|}{ Influent } \\
\hline & & \multicolumn{2}{|c|}{$\mathrm{NH}_{3}(\mu \mathrm{g}-\mathrm{N} / l)$} & 950 & 700 & 750 & 940 & 1,000 \\
\hline & & \multirow{2}{*}{$\begin{array}{l}\mathrm{NO}_{2} \\
\mathrm{NO}_{3} \mathrm{C}\end{array}$} & $"$ ) & 120 & 120 & 100 & 80 & 100 \\
\hline & & & $7)$ & 820 & 430 & 600 & 700 & 680 \\
\hline & Sol. Org. & $\mathrm{N}$ & $" \quad)$ & 8,000 & 6,300 & 3,600 & 8,400 & 3,600 \\
\hline & Part. Org. & $\mathbf{N}($ & $n \quad$ & 7,300 & 7,000 & 7,900 & 10,900 & 6,500 \\
\hline & Total & $\mathrm{N}($ & $\pi j$ & 17,200 & 14,500 & 12,900 & 21,000 & 11,800 \\
\hline \multicolumn{9}{|l|}{ Effluent } \\
\hline & & \multicolumn{2}{|c|}{$\mathrm{NH}_{3}(\mu \mathrm{g}-\mathrm{N} / l)$} & 360 & 160 & 630 & 710 & 220 \\
\hline & & $\mathrm{NO}_{2}($ & $n \quad)$ & 19 & 52 & 30 & 68 & 45 \\
\hline & & $\mathrm{NO}_{3}($ & $n \quad)$ & 240 & 800 & 980 & 490 & 1,060 \\
\hline & Sol. Org. & $N \quad($ & 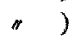 & 50 & 470 & 500 & 50 & 50 \\
\hline & Part. Org. & $\mathrm{N}$ & $7 \quad)$ & 300 & 870 & 65 & 360 & 80 \\
\hline & Total & $\mathbf{N}$ & $n)$ & 970 & 2,350 & 2,280 & 1,670 & 1,450 \\
\hline \multicolumn{4}{|c|}{ Removal rate of $\mathrm{N}(\%)$} & 93 & 84 & 82 & 92 & 88 \\
\hline
\end{tabular}

the bottom of lagoon as the mud, in which nitrogen content reached almost a half of whole nitrogen reserved in the lagoon.

As shown in Table 2 and Fig. 3 a grand total of nitrogen reserved in mud and mixed liquor did not increase in the test period, while in the preceding winter it increased considerably. The facts seem to indicate that the suspended state of sludge make accelerate a nitrification and denitrification of nitrogen, giving a condition to make good contact with fresh influent water, which would play a role of electron donor for denitrification, and also a high concentration of MLSS caused by strong mixing makes it possible to prevent an excess oxygen supply.

\section{Aknowledgement}

The author wishes to thank to Dr, Y. Yoshida for useful instructions and advice, and also to the
Osaka Prefectural Government for supplemental financial support for this study, by which a part of this experiment was managed.

\section{References}

1) K. Mrtsuhashi and Y. Yoshida: Bull. Japan. Soc. Sci. Fish., 44, 1257-1260 (1978).

2) K. MrtsuHashi and Y. Yoshida: Bull. Japan. Soc. Sci. Fish., 44, 1261-1264 (1978).

3) W. W. ECKENFelder Jr.: Industrial Water Pollution Control, McGraw-Hill, Inc, New York, 1966, pp. 199-207.

4) W. W. ECKENFELDER Jr. and D. J. O'CONNER: Biological Waste Treatment, Pergamon Press, New York, 1961, p. 199.

5) M. Soexma and K. Sugahara: Tanpakushitsu no Teiryoho, 1st ed., Tokyo daigaku Shuppankai, Tokyo, 1971, pp. 28-29.

6) Japanese Industrial Standard Committee: Testing Methods for Industrial Waste Water IS KO102, 1974, p. 40. 